\title{
The Dialectic of Progress and the Cultivation of Resistance in Critical Social Theory
}

\author{
in Social Epistemology (2021)
}

This is the penultimate, pre-proof version-please cite the final version found at: https://doi.org/10.1080/02691728.2021.2000663

\author{
Iaan Reynolds \\ Villanova University \\ christiaan.reynolds@,villanova.edu
}

\begin{abstract}
Beginning with the influential discussion of the dialectic of progress found in Amy Allen's The End of Progress, this paper outlines some difficulties encountered by critical theories of normative justification drawing on the early Frankfurt School. Characterizing Adorno and Horkheimer's critical social theory as a dialectical reflection eschewing questions of normative foundations, I relate their well-known treatment of the dialectic of enlightenment reason and myth to their critique of capitalist society as a negative totality. By exploring the concepts of historical development used by Adorno and Horkheimer to describe both the progressive domination of capitalism, and the formation and cultivation of reflective consciousness, I trace the importance of progression and its inseparable relationship to regression in these early versions of critical theory. The dialectical social theory found here recognizes the persistence of social contradictions on both a methodological level and on the level of theory's development and expression, a connection potentially obscured by a division of historical progress according to its temporal orientation. Particularly in Adorno's later work, an opposition to the negative social totality requires notions of cultivation and learning which work against the prevailing forms of conceptual thinking, including the concern for the stability of rational foundations.
\end{abstract}

KEYWORDS: critical theory, progress, social theory, capitalism, dialectics, education

\section{FULL TEXT}

According to Max Horkheimer and Theodor W. Adorno's Dialectic of Enlightenment (2002), the development of humanity's mastery over nature begets servitude to a 'second nature' produced in this process. In this dialectical interplay, nature takes revenge against reason's attempts to control it by imprisoning humankind in an administered society of its own making. Social theory stemming from this observation is unable to designate historical developments unambiguously, viewing 
history instead as an intertwined complex of progress and regression, domination and conciliation, enlightenment reason and myth. The critique of reason's development in history forsakes the stability of an established position, in favor of a continually moving dialectic. Since this project must abandon the possibility of a fixed perspective from which they can be resolved, oppositions such as the one between progress and regression are understood to pertain not only to the theoretical systems of social research—conditioning its methods and objects—but also to the subjective conditions allowing for the formation and cultivation of critique. Adorno's work is particularly notable for its recognition of this connection, relating an incisive critique of capitalist society to a concern for the development of self-reflection. The following sections explore a few challenges facing this endeavor, particularly relating to the way in which the interrelation of progress and regression affects the methodological dimensions of critical social theory, and the possibility of its expression.

I begin with the influential discussion of the dialectic of progress found in Amy Allen's The End of Progress: Decolonizing the Normative Foundations of Critical Theory (2016). Taking this work's intention to decolonize critique's normative foundations as a point of departure, I suggest that such a project's return to the social thought of the early Frankfurt School is problematic, since Adorno and Horkheimer's dialectical social theory eschews the need for a foundation or justification of its normative commitments (Section 1). The next two sections explore the concepts of historical development used by Adorno and Horkheimer, concerning the progressive domination of capitalism (Section 2), and the formation and cultivation of critical reflection (Section 3). Though they are not employed to ground normative principles, these processes are nevertheless centrally important to understand as forms of progressive development, for a critical theory as a critique of capitalist society. 


\section{The Critique of Progress and the Need for Normative Foundations}

Since Jürgen Habermas' work in the 1970s and '80s, the Frankfurt School tradition of critical theory has turned much of its theoretical attention to the justification and application of normative principles, distancing itself in this regard from the early thinkers of this tradition, such as Adorno and Horkheimer. ${ }^{1}$ Habermas' critique of Adorno and Horkheimer's Dialectic of Enlightenment, for example, claims that its entwinement of myth and enlightenment nullifies the advances of modernity by turning reason against itself. According to this account, the first generation of critical theory makes claims about the wrongness of contemporary life, but simultaneously revokes its ability to justify these claims through its conception of the totalizing force of enlightenment rationality. ${ }^{2}$ Against this nihilistic tendency to 'take leave of modernity,' Habermas seeks to 'retriev[e] the normative content of modernity,' by separating the realm of instrumental rationality from the lifeworld of intersubjective communication that grounds it (Habermas 1987, 336, 347). Grounded on a conception of modernity as the differentiation of value spheres, Habermas' social theory maintains the authority of instrumental reason within its own delimited sphere, while clearly defining a role for normatively oriented criticism in checking the 'colonizing' overextension of instrumental rationality into the lifeworld.

Critical theorists following Habermas' critique of Adorno and Horkheimer have similarly devoted considerable attention to the source and justification of the normative principles guiding critique, often relying in this effort on a positive, if qualified, assessment of enlightenment

${ }^{1}$ See, Finlayson (2007), Bernstein (2001, 96ff.), Honneth (1979), and Hullot-Kentor (2006) for more detailed treatments of this history.

${ }^{2}$ As James Gordon Finlayson writes of Adorno and Horkheimer: 'Thus they maneuver themselves into the dilemma described above: they cannot adduce the broadly moral considerations their conclusions require on pain of inconsistency; but if they do not, the claims of their critical theory remain unsupported' (Finlayson 2007, 667). 
rationality. Beginning with contemporary critical theory's tendency to ground critique's moral and political principles on a conception of historical enlightenment, Amy Allen's The End of Progress identifies a serious problem in this tradition. Although narratives of progress or historical learning might seem plausible to comfortably situated residents of Western European countries, a more sensitive approach to history yields a bleaker view of the modern world. The dream of enlightenment was a nightmare for countless millions whose enslavement, colonial subordination and dehumanization were merely the other side of humanity's apparent advances (Allen 2016, 3). Owing to the troubling way in which concepts of enlightenment progress tend to erase the exploitation underpinning the history of capitalism and colonialism, Allen thus argues that "critical theory's approach to grounding normativity must be radically transformed' (Allen 2016, 4).

In her project of decolonizing critical theory by transforming its approach to normative foundations, Allen argues that we ought to 'disentangle' the pernicious narratives of moral and political progress in the past from a forward-looking conception of progress to come, or progress as an imperative (Allen 2016, 16). Drawing on Walter Benjamin's and Adorno's writings on history, Allen argues that a forward-looking conception of progress - understood as the alleviation of suffering - is centrally important for these authors, even as they reject problematic backwardlooking conceptions of progress. The futural and imperative form of progress outlined in Benjamin and Adorno, and adopted by Allen, is based on the capacity to imagine a world wholly different from the present one. At the same time, the hope for the alleviation of suffering can only be realized when we abandon our attachment to the past as a source of affirmative political and moral value. In this way, Allen makes sense of the Adorno passage framing the title of her work: 'Progress occurs where it ends' (Adorno 2005b, 150; Allen 2016, 26). According to Allen's reading of this quote, the progressive elimination of injustice is only possible once we have disabused ourselves 
of a backward-looking narrative of historical advancement. Freeing reflection on political possibilities from the weight of past injustices, Allen's critical theory seeks to make possible a new world without basing it on the image of the old.

Allen's work has been widely discussed, owing to its profound criticism of certain strands of contemporary critical theory. ${ }^{3}$ For our purposes here, I only want to raise one question pertaining to the difficulty of incorporating Adorno and other first-generation Frankfurt School thinkers into a project of critical theory as normative critique. As we have already begun to see, this latter conception of critical theory developed partially as a response to apparent shortcomings in Adorno and Horkheimer's theoretical orientation. While the early critical theorists' reflections on historical progress convincingly question narratives of teleological advancement, unidirectional development, and other enlightenment myths, it is thus unclear whether the way they reject these myths could become helpful for a program maintaining a commitment to the justification and application of normative principles. ${ }^{4}$ For Adorno and Horkheimer, critical theory's moral and political dimension rests on basic human experiences which, they consistently argue, require no theoretical elaboration - such as the bodily experience of suffering and humankind's hopeful striving for happiness. ${ }^{5}$ In an early juxtaposition of his project against contemporary moral

${ }^{3}$ For critical discussions, see, e.g., Vogelmann (2021, who also includes a more extensive list at 12 n.2), Nichols (2018), and Vázquez-Arroyo (2018).

${ }^{4}$ Some commentators similarly question the centrality of normative criticism, arguing, for instance, for a break from normative justification in favor of a 'humbler... more radical' critical theory (Vogelmann 2021, 11; Freyenhagen 2017, 9 n. 2), that this emphasis obstructs critical theory from the critique of capitalist society (O'Kane 2021, 214; Lotz 2014, xii-xiv), and that concern with normative foundations is one important part of a broader project also involving the important question of the relationship between theoretical work and the practical work of political movements (Celikates 2018, 217-218).

5 'The materialist view has the negative significance that it rejects a metaphysically grounded morality. But in addition it has always meant to materialists that man's striving for happiness is to be recognized as a natural fact requiring no justification' (Horkheimer 1992a, 44); 'The premier demand upon all education is that Auschwitz not happen again. Its priority before any other requirement is such that I believe I need not and should not justify it... To justify it would be monstrous in the face of the monstrosity that took place' (Adorno 2005a, 191). 
philosophies, for example, Horkheimer states that the materialist social theorist 'regards justification as an illusion' (Horkheimer 1992a, 23). Instead of a justification or rational reconstruction of the normative commitments immanent to the social world, Adorno and Horkheimer's works outline a negatively dialectical social theory that responds to suffering in a contradictory society by reflecting on the simultaneous necessity and contingency of these conditions.

Since a rational account of critique's normative foundations plays no substantial role in Adorno and Horkheimer's critical theory, it seems unlikely that the separation between backwardlooking and forward-looking progress - a theoretical move specifically linked to the use of progress to ground critique's normative orientation - fully captures the dialectic of progress in these works. In fact, as we will see, these early instances of critical theory rely on concepts of progressive development that are indispensable both for properly conceiving the objects of critique, and for cultivating its lived possibility. A dialectic of progress and regression pertaining at once to critical theory's method as a critique of capitalist society, and to its concrete prospect as the education of critical consciousness, is unable to abandon a backward-looking conception of progress, even though the notions development it does retain will remain inseparably bound up with the possibility of their reversal.

\section{Progress and Regress in the Negative Social Totality}

In his writings on the aims and methods of critical theory in the 1930s, Max Horkheimer contrasted this program of social research with the 'traditional theory' of the contemporary sciences. Traditional theory is distinguished by its uncritical immersion in the social division of labor, taking its goals, theoretical orientations, and categories from extant social conditions and institutions without reflecting on the 'social function' of scientific research (Horkheimer 1992c, 197). Social 
philosophy that adopts society's dominant instrumentalizing tendency is, according to Horkheimer, 'no longer the critic, but the servant of science and the social forms in general' (Horkheimer 1992b, 262). Through these social forms, society pre-figures not only the imaginative possibilities and sense perception of its members (see, e.g., Horkheimer 1992c, 201), but also the theoretical tools of social scientists. By expressing and expanding capitalist society's prevailing modes of consciousness, traditional theory facilitates the continuous production and reproduction of contemporary social and political conditions. Critical theory, on the other hand, strives against this production and reproduction by resisting the dominance of the reified social forms. Its reflections seek a form of knowledge taking society as its object, without accepting the preformed struggles within this society as its own (Horkheimer 1992c, 207).

Since critical theory resists the social division of labor in which it is nevertheless immersed, it cannot avail itself of the unambiguous categories and seemingly well-defined objects of study available to the traditional theorist. Critique thus begins from a recognition of the 'two-sided character of social reality' (Horkheimer 1992c, 207-8). On the one hand, contemporary social institutions and forms can be seen as the product of human effort and productivity; from this side, society appears as a historically variable product of human agency. On the other hand, the social world also appears to be determined by factors outstripping the freedom of any individual; from this side, society seems unchangeable and quasi-natural, determined by the laws of capitalist accumulation. Critical theory strives to bring this antagonism-between the humans making up society, and the relations determining its organization-into consciousness through reflection. In its struggle to bring unconscious contradictions to consciousness, this dialectical social theory discovers the conceptual and socio-material oppositions of a society so rent by antagonism that it cannot be seen as a whole from within itself; as the development of self-consciousness within this 
society, critical theory attempts nevertheless to understand society's contradictory dimensions as parts of a single system.

A society bearing real contradictions in its organization cannot be represented in unambiguous terms. As Adorno writes in his 1961 debate with Karl Popper: 'reality opposes the clean, systematic unity of assembled statements' (Adorno 1976a, 106). Against approaches to sociological methodology such as Popper's, with their emphasis on empirically measurable conditions, Adorno's social theory focuses its attention on society as a whole, while maintaining a commitment to understanding the thoroughgoing conceptual difficulties facing any theoretical account of this whole:

Society is full of contradictions and yet determinable; rational and irrational in one, a system and yet fragmented; blind nature and yet mediated by consciousness. The sociological mode of procedure must bow to this. Otherwise, out of puristic zeal to avoid contradiction, it will fall into the most fatal contradiction of all, namely, that existing between its own structure and that of its object. (Adorno 1976a, 106)

The self-contradictory nature of society requires a theory that reflects its oppositions in the form of presentation. Critical theory thus opposes a view of the social order as an objective realm capable of unambiguous expression. Instead, dialectical social theory focuses on the antagonisms and contradictions underlying the social whole, resulting in a critique of capitalist political economy and its distinct forms of conceptuality. ${ }^{6}$

Because they depend on a logic that renders dissimilar objects identical, the relations structuring capitalist society hide nonidentity behind the façade of conceptual clarity. Although the act of exchange, for example, seems to depend on a form of equivalence between exchanged

\footnotetext{
${ }^{6}$ On critical theory as a critique of capitalist political economy, see, e.g., Bonefeld (2014), Prusik (2020), and O'Kane (2021).
} 
objects, this equivalence is the result of an abstraction from their use value. The nonequivalence concealed by this act of abstraction indexes an imbalance of power: 'From olden times, the main characteristic of the exchange of equivalents has been that unequal things would be exchanged in its name, that the surplus value of labor would be appropriated' (Adorno 1995, 146). At the same time, the dominance of the exchange principle relies on this inequality: if the exchange of labor power for wages did not expropriate the worker, the system of capitalist accumulation would not function. ${ }^{7}$ The basic forms of capitalist society thus rely on a nonidentity that masks itself: these concepts are not what they appear to be. Exchange, for example, possesses 'real objectivity' at the same time as it is 'objectively untrue... transgressing against its own principle, the principle of equality' (Adorno 1995, 190). ${ }^{8}$ The free exchange of commodities and labor on the open market is merely an ideological mask covering the deeper reality of compulsion and the threat of immiseration. The consciousness of social actors within a system structured by these abstract social forms hides the profound contradiction between the appearance and reality of society. ${ }^{9}$ The illusory nature of these categories generates the foundational problem confronting social theory.

Like the exchange principle to which it is fundamentally related (Adorno 1995, 146), the process of conceptual identification - through which particular experiences are subsumed under a concept - tends to repress the moments of particularity outstripping the concept. In capitalist society, this tendency of thought to subsume particulars under general concepts is turned into a social necessity. Despite its pretensions to totality and universality, exchange society nevertheless

\footnotetext{
7 'If no man had part of his labor withheld from him anymore, rational identity would be a fact, and society would have transcended the identifying mode of thinking' (Adorno 1995, 147).

${ }^{8}$ See Prusik (2020, chap. 1) for a helpful account of identity thinking and its relation to the abstract forms of capitalist society.

9 'Exchange value, merely a mental configuration when compared with use value, dominates human needs and replaces them; illusion dominates reality' (Adorno 1976b, 80).
} 
produces moments of irreconcilable particularity, obstinate nonidentity, within itself. The challenge of conceiving this system - a totality that is not identical to itself, since its concepts mask both the relations of domination underlying them, and their own masking function - leads Adorno to the conception of society as an 'antagonistic entirety,' or negative totality (Adorno 1995, 10). By 'grasping' the contradictory nature of the social totality and 'extending rationality to it' (Adorno 1976a, 109), Adorno's social theory expresses the outline of this totality through attention to the moments not yet assimilated to its logic. Through dialectical thinking, the theorist develops a 'consistent sense of nonidentity' (Adorno 1995, 5), which opposes the social totality by 'convicting it of nonidentity with itself' (Adorno 1995, 147).

In the Dialectic of Enlightenment, the basic theoretical components of Adorno and Horkheimer's broader projects are brought to account for the historical relationship between reason and nature. The identification at the basis of conceptual thinking, and thus at the basis of rationality itself, is here understood as the source both of an empowerment of humans over nature, and a deepening of nature's power over humans. At the same time as the conceptual tools through which mastery is attained tend to distance and elevate humanity above nature, they also bind humankind in the spell of identity-thinking, which is nearly impossible to escape once its function as 'separating, distancing, and objectifying' is obscured (Horkheimer and Adorno 2002, 31). Enlightenment's avowed opposition of itself to superstitious and mythological primitivity thus conceals a more ambiguous dynamic: 'Enlightenment is more than enlightenment, it is nature made audible in its estrangement... In the mastery of nature, without which mind does not exist, enslavement to nature persists' (Horkheimer and Adorno 2002, 31). The complicated relationship between conceptual thinking and mythology spells out the famous thesis of this work: "Myth is already enlightenment, and enlightenment reverts to mythology' (Horkheimer and Adorno 2002, 
xviii). In its dialectic of enlightenment, reason's compulsion to separate itself from nature paradoxically imprisons humanity in a world built in the image of dominating rationality.

The interrelation of reason and myth might give us the sense that this work resorts to a pessimistic and uncritical destruction of reason. ${ }^{10}$ It is true, to be sure, that Adorno and Horkheimer can lay no unambiguous claim to enlightenment rationality, nor to a realm of reason sealed off from the workings of power. ${ }^{11}$ But it is not merely the case that dialectical critique casts what appears to be natural - such as humanity's claim to reason - into a historically contingent phenomenon bound up with the workings of power; nor merely that it understands the apparently free choices of members of society as expressions of a social necessity outstripping their control. Rather, critical theory works on both levels at once - historicizing what appears natural, and naturalizing what appears historical, so to speak - in order to free humanity from the hold of the social relations and conceptual identifications perpetuating domination. ${ }^{12}$ Dialectical reflection's continual motion pushes opposed terms - such as myth and enlightenment, or nature and history - to 'a point where they are mediated in their apparent difference,' as Adorno writes in his 1932 essay on natural history (Adorno 2006b, 253). In deepening this line of thinking, Adorno and Horkheimer do not merely invalidate reason by considering it one-sidedly as the expression of power, but also disrupt dominating reason's claim to totality through attention to the particular moments escaping its grasp. Through a self-reflection that confronts modern society with its own nonidentity, Adorno and Horkheimer hope to free reason from the spell of identity thinking by reflecting on and identifying this compulsion itself. ${ }^{13}$ The overarching aim is thus less about

\footnotetext{
${ }^{10}$ See, Habermas (1987, lecture 5).

${ }^{11}$ As Allen notes $(2016,186 \mathrm{ff}$.), reason and power are profoundly intertwined.

${ }^{12}$ See Adorno (2006a, 133-34).

13 'If enlightenment does not assimilate reflection on this regressive moment, it seals its own fate' (Horkheimer and Adorno 2002, xvi).
} 
destroying or invalidating reason, than it is about allowing the critical use of reason the space to move in an uncompelled way. Far from sliding into irrationalism or relativism, Adorno and Horkheimer hope for a form of reason that could redeem humanity. ${ }^{14}$

For Adorno and Horkheimer, enlightenment is 'both progress and regress at the same time' (Allen 2016, 166). From the foregoing outline of dialectical social theory, it is clear that the dialectic of progression and regression sees in each of these terms a distinct possibility for understanding history. Consequently, the hope that pervades the Dialectic of Enlightenment for a critical use of reason cannot be stringently justified or grounded in an affirmative understanding of history without dissolving. To cast the development of reason in an unambiguous light arrests the dialectic, violently subsuming a complex history under a simple concept. As Adorno writes in his 1964-65 lecture course on History and Freedom:

What makes the concept of progress dialectical, in a strictly non-metaphorical sense, is the fact that reason, its organ, is just one thing. That is to say, it does not contain two strata, one that dominates nature and one that conciliates it. Both strata share in all its aspects. (Adorno 2006a, 157) ${ }^{15}$

A critical form of reason that could liberate humanity from the mythical spell of progress narratives is impossible to separate or extricate from reason as domination, since the reason that dominates and the reason that conciliates are one and the same. The possibility of reconciliation is thus directly conditioned by its contradictory opposite: 'the precondition of freedom is the unfreedom that precedes it' (Adorno 2006a, 150).

${ }^{14}$ Concerning the hopeful conception of enlightenment rationality, see also: Adorno (1976a, 121-22), Allen $(2016,167)$ and Huseyinzadegan $(2018,468-69)$.

${ }^{15}$ See Adorno $(2005 b, 152)$ for a similar formulation. 
The underlying unity of reason means that the conditions furthering the domination of humankind also determine the form of reflection that could imagine a humankind freed from these conditions. Adorno and Horkheimer write:

Each advance of civilization has renewed not only mastery but also the prospect of its alleviation. However, while real history is woven from real suffering, which certainly does not diminish in proportion to the increase in the means of abolishing it, the fulfillment of that prospect depends on the concept. For not only does the concept, as science, distance human beings from nature, but, as the self-reflection of thought - which, in the form of science, remains fettered to the blind economic tendency - it enables the distance which perpetuates injustice to be measured. (Horkheimer and Adorno 2002, 32)

While instrumental domination deepens the exchange society's control over every dimension of human life, these expansions of mastery also sow the seeds of their own overcoming, since they condition a possible use of reason unchained to this society's false needs and illusory forms. The distance achieved by reason in its progressive domination of nature is also understood here to allow a conceptual apprehension of suffering and its role in the social totality. Although we might be tempted by present modes of domination and the threat of new technologies to deny the fact of any progress, these developments allow for a world where new possibilities can be imagined. As Adorno writes of the pessimism inspired by the hydrogen bomb: 'in the age of the bomb a condition can be envisaged for the first time in which violence might vanish altogether' (Adorno 2005b, 153). ${ }^{16}$ The increase in economic productivity and development of the technical forces of production - while certainly not understood as a morally unambiguous improvement - are nevertheless developmental processes with concretely discernible tendencies, which 'create the

${ }^{16}$ Allen $(2016,167)$ discusses this line of thinking in Adorno and Horkheimer, but without stressing the way that critical reason's reliance on historical developments that must be understood progressively.

Reynolds 13 
conditions for a more just world' (Horkheimer and Adorno 2002, xvii). The developments of capitalist society create a social totality whose negative is a society free of want and suffering. ${ }^{17}$

Understanding progress and regression dialectically certainly implies a rejection of selfcongratulatory narratives of enlightenment reason. These mythological stories sacrifice the critical use of reason for an instrumentalizing compulsion that threatens to become total. At the same time, however, this dialectic cannot be resolved by dividing progress according to its temporal orientation - thus rejecting any conception of backward-looking progress. In humanity's progression and regression, each of which can be discerned in every historical process, social theory locates an interrelated dynamic that must be reflected in all its complexity. Since we cannot conceive a world without hunger absent the conditions created by the development of the technical means of mass production and distribution, the project of critical theory is inseparable from the critique of capitalist society. For those suffering under present conditions, the capacity to understand these conditions in terms of a process of development whose rationality can be discerned, and whose functioning can thus be interrupted, is of great importance. Critical social theory is thus obliged to retain a conception of backward-looking historical progress, in order to apprehend the expansion of capitalist social forms, and their increasing domination of social, cultural, and global reality. ${ }^{18}$

Adorno and Horkheimer's social thought stems from a realization that the avoidance of catastrophe requires a transformation of reason itself through a negative self-reflection. Realizing

17 'Material needs, which long seemed to mock progress, have been potentially eliminated; thanks to the present state of the technical forces of production no one on the planet need suffer deprivation anymore' (Adorno 2005b, 144).

${ }^{18}$ As Robert Nichols suggests, social theorists committed to a critique of capitalism and colonialism but uncommitted to the conception of critical theory as normative critique often use 'progress' to refer to the expansion and universalization of capitalist social relations (Nichols 2018, 784). 
this emancipatory form of rationality is a formidable theoretical and practical challenge. In Adorno's essay titled 'Progress,' for example, the prospect of emancipation rests on a humanizing transformation of all society: 'Whether there will be further want and oppression-which are the same thing - will be decided solely by the avoidance of catastrophe through the rational establishment of the whole society as humanity' (Adorno 2005b, 144). ${ }^{19}$ As Allen is right to note, Adorno is committed to a form of progress that looks forward. But as we have seen here, this hope of a society befitting humanity is also conditioned on the advances and developments of the pasteven if the 'progress' of these developments is not understood in a moral way. Indeed, Adorno's 'end of progress' severs the mythological link between the development of material conditions and social relations on the one hand, and moral and political advancement on the other.

If it is to understand the growing domination of capitalist social relations and the forms of consciousness they engender, however, critique must also necessarily work against prevailing conceptions of straightforwardly useful—or even apparently 'rational'—philosophical work. Predominant forms of rationality and the institutions in which they are embedded are not what they say they are, and critical theory's reflection on this nonidentity recognizes that its obstinacy is bound up with the identifications making rationality possible in the first place. This recognition is extended, ultimately, to the work of theorizing itself: the critique of capitalism, as the Dialectic of Enlightenment's sweeping historical scope shows, is also more than a critique of capitalism. Critical reflection on this dialectic calls for methods and modes of work that are not yet possible, necessarily resisting thought's tendency to stability within clearly demarcated bounds. The social theory outlined here is thus resistant to the stasis that would allow for a clear separation of

\footnotetext{
${ }^{19}$ In his 'Materialism and Morality,' Horkheimer similarly outlines a moral sentiment that sees everyone as a member of a "potentially liberated humanity" (Horkheimer 1993, 33-34).
} 
conciliatory from dominating rationality, lifeworld from system, or normative justification from instrumental manipulation. This does not mean, however, that early critical theory has no criteria of development. As we will see, Adorno understands the formation and cultivation of the kind of critical reflection we have begun to outline here, as itself a developmental process.

\section{Critique and the Cultivation of Reflexivity}

Critical theory as negative reflection seems incapable of producing positive prescriptions for political change. Specifying a political program would appear to lead critique into the trap of instrumental rationality. Accordingly, the early Frankfurt School theorists are often depicted as avoiding questions of political practice in favor of isolated aesthetic reflection. In a characteristic characterization of Adorno's work, for example, Axel Honneth writes, 'Only individually produced art offers the possibility of a rationality which is able to resist reification and provide society with the possibility of liberation' (Honneth 1979, 57). The centrality of aesthetic experience as a form of resistant consciousness is certainly helpful for understanding one aspect of Adorno's project, since opposing the totalizing exchange society requires an insistence on the possibility of modes of experience and sensibility not yet preformed by this order. At the same time, a focus on Adorno's aesthetic reflections as the key to understanding social practice in his thought limits our understanding of critical theory, since the new sensibility outlined in Adorno's work is clearly not limited to art. ${ }^{20}$ While commentators are right to note that Adorno offers little in the way of a clearly drawn image of the just society, ${ }^{21}$ the thesis of an exclusively aesthetic resistance threatens to obscure the importance of Adorno's sustained interdisciplinary program of

${ }^{20}$ In fact, the separation of 'aesthetic' considerations from broader questions of reason and enlightenment is a theoretical tendency at odds with the broader enlightenment tradition, and one certainly resisted by Adorno. See, e.g., Hullot-Kentor (2006, 32ff.), Bernstein (2001, ix, 4), and Finlayson (2007, 655ff.).

${ }^{21}$ Adorno and Horkheimer's critical adoption and modification of the Old Testament 'ban on images' (Bilderverbot) of God can be found, e.g., at Horkheimer and Adorno (2002, 16-17). 
social research in the postwar period, including his underappreciated reflections on the formation of critical consciousness.

In scattered discussions of the cultivation of reflexivity, Adorno recognizes the necessity to conceive of education outside of the instrumentalizing frame he and Horkheimer ascribe to capitalist society. In this context, Adorno develops his treatment of contemporary education as Halbbildung (half-formation or half-education; Adorno 1993). The traditional concept of Bildung (formation, cultivation, education), which named a process of humanity transcending itself, has degenerated, according to Adorno, into a mutilated half-version of cultivation. Education has become degraded to a form of thinking that bows before the facts, providing students with scarce and increasingly monetized resources in their individual struggles for self-preservation. Through the family, educational institutions, and other systems of discipline, individuals are stamped with the techniques of identification and conceptualization necessary to fulfil their needs within the prevailing system of rewards and punishments, but are simultaneously deprived of those qualities that would allow them to become self-determining and autonomous subjects: 'in a society which has lost virtually all of its qualities as a result of the domination of the exchange principle, the individual gains neither form nor structure, the elements which enable him to cultivate himself in the most literal sense of the term' (Adorno 1993, 24). In this way, 'education' in capitalist society develops calculative rationality at the expense of a critical form of reason capable of resisting the prevailing forms of life and thought. Obstructed in this way, reason ceases to transcend its social conditions. For a subject deformed by this half-education, resistance appears useless.

The apparent impossibility of resistance is related, in Adorno's postwar writings, to thought's tendency to ossify into forms that block self-reflection. ${ }^{22}$ In various essays and public

22 'Regression of consciousness is a product of its lack of self-reflection' (Adorno 1995, 149). 
addresses, Adorno links the prevailing lack of reflection to the enduring threat of fascism. The 1966 radio address titled 'Education After Auschwitz,' for example, focuses on educational methods to work against the repressed forces of barbarism and lack of reflection pervading society. Achieving a form of education that could make the repetition of Auschwitz impossible - a need so urgent that attempts to justify it would be 'monstrous' (Adorno 2005a, 191)-requires a commitment to the development of self-reflection: '[t]he only education that has any sense at all is an education toward critical self-reflection' (Adorno 2005a, 193). Critical reflection unsettles the logic of the social system by interrupting the second-nature reactions through which this system maintains itself, opening the possibility of making conscious the previously unconscious factors conditioning this society's reproduction. ${ }^{23}$ By reflecting on their prejudices and intellectual reflexes, individuals might begin to de-naturalize their apparently 'unalterable' and 'given' modes of social existence and understand them to be the result of 'historical evolution' (Adorno 2005a, 200), becoming in this way empowered to rationally determine their lives in opposition to the social order. ${ }^{24}$

These essays and radio addresses display the importance of concepts of Bildung and Mündigkeit (responsibility, autonomy) in Adorno's work, although these concepts are difficult to explicate fully, and must be broken out of their dominant forms ${ }^{25}$ Just as overarching narratives of historical progress subordinate consciousness to dominant social tendencies, narratives of educational progress as a teleological acquisition of job skills similarly extinguish the possibility of critique. Nevertheless, resisting the dominant mode of education requires the formation of an

23 'The only way spirit can possibly survive is through critical reflection on pseudo-culture, for which culture is essential' (Adorno 1993, 38).

${ }^{24}$ Adorno outlines a similar practice in 'The Meaning of Working Through the Past' (Adorno 2005c, 102).

${ }^{25}$ As well as Adorno’s 1969 interview with Hellmuth Becker (Adorno and Becker 1999), see Cook (2020) on Adorno's conception of enlightenment. 
openness to transformation through self-reflection, and thus to a critical form of philosophical experience. Those engaged in this form of education discover and cultivate a familiarity with their own limitations, and the illusory forms of social consciousness they bear. ${ }^{26}$ As an open-ended selfreflection meant to unsettle the overarching logic of the social order, critique "breaks through the economy of self-preservation and immanence, that is, the semblance of the ego' (Thompson 2006, 82), in order to make possible a subject that does not yet exist - a subject of free humanity whose outlines can only be seen in fragmented form. ${ }^{27}$

Adorno recognizes that representing critical philosophical experience requires new kinds of intellectual effort. There is accordingly no fully worked-out theory of education for reflexivity in his work. Many of the clearest expressions of this commitment on his part, aside from the essays and radio addresses already cited, are found in his lectures, in which Adorno is surprisingly forthright in advising his students in the lifelong educational process of 'work[ing] critically on [them]selves' (Adorno 2019, 109). Although we can only discern this task—and the difficulties it encounters - in negative outline, Adorno is clearly dedicated to the education of a critical sensibility. In many cases, what might appear to be purely aesthetic reflections are understood as the work of cultivating a resistant sensibility - a project certainly touching on the realm of aesthetic experience with which Adorno is often associated, but also extending into broader questions of social and political education.

As we saw in the last section, Adorno and Horkheimer's critical theory recognizes the necessity of theoretical concepts of progressive development pertaining to the growth of capitalist society. We can now see, in closing, how these methodological dimensions of critical theory,

${ }^{26}$ Thompson (2006) provides an excellent introduction to this discussion.

${ }^{27}$ See for example, Walter Benjamin's (2003) theme of a redeemed humankind in his 'Theses on the Concept of History.' 
pertaining to its object of study, are also related to the need for a substantive conception of progress, as a lived process of development, within this tradition. If a critical account of the negative totality of capitalist society demands theoretical sensitivity to the historical developments of capitalist social relations and technological forces, the critical reflection capable of expressing this totality in all its negativity must itself undergo a process of development, seen first and foremost in the development of the critic. In this learning process, what might appear to be purely aesthetic considerations are in fact expressions of a progressive movement toward a critical sensibility.

In his 1957 piece, 'The Essay as Form,' for example, Adorno describes the cultivation of consciousness through a consideration of the essay as an aesthetic form. In its 'methodically unmethodical' character, the essay allows the development and expression of a form of conceptuality gesturing beyond itself, moving 'culture to become mindful of its own untruth, of the ideological illusion in which culture reveals its bondage to nature' (Adorno 1991, 20). The essay allows the expression of thoughts that are not yet possible but are neither merely fantastical images without foundation. However, this also means that this literary form sacrifices a claim to internal consistency: 'Its concepts are not derived from a first principle, nor do they fill out to become ultimate principles' (Adorno 1991, 4). Paying for its emphatic conception of truth with a lack of conceptual security, the essay works with concepts whose meaning is still in formation. Accordingly, this kind of work requires an openness to intellectual experience that outstrips the individual author. The theorist is not a herald of metaphysical insight, nor an empirical investigator trying to uncover truth through trial and error, but is rather conceived as 'an arena for intellectual experience' (Adorno 1991, 13). Adorno writes:

This kind of learning remains vulnerable to error, as does the essay as form; it has to pay for its affinity with open intellectual experience with a lack of security that 
the norm of established thought fears like death. It is not so much that the essay neglects indubitable certainty as that it abrogates it as an ideal. The essay becomes true in its progress, which drives it beyond itself, not in a treasure-hunting obsession with foundations. (Adorno 1991, 13)

Far from mounting a merely stylistic opposition to the negative social totality, Adorno's philosophy proceeds from the recognition that the concepts that would allow true insight into this totality are not readily available within it but must be made possible through reflection. This recognition has its effect on style, just as it bears its own conception of truth. The oppositional philosophical experience cultivated by critical theory cannot aim merely at a superior scientific grounding of sociological methods, nor a more clearly defined moral orientation, without a transformation of the element of its expression, and ultimately of the critic themselves. Critical reflection's advance thus brings it into contact with that which has not yet been conceptually subsumed, not in order to celebrate it as an irrational basis of knowledge, but rather to transform itself through relationship with the nonidentical. In this drive beyond itself, conceptual thinking attains a form of truth that it could not achieve through a meditation on foundations. This conception of critical theory moves beyond the justification or retrieval of normative principles precisely because its task lies in the cultivation of 'the consistent sense of nonidentity' (Adorno 1995, 5), and thus in the possibility of a resistance whose concrete practice is still in formation. In its ever-renewed struggle for self-transformation, philosophical critique aspires to a new relationship to itself and the social world, from within the negativity of the present. 


\section{ACKNOWLEDGEMENTS}

The author would like to thank Harrison Farina, Elizabeth Portella Perreras, Charles Prusik and Delia Popa for their comments on earlier versions of this paper, as well as an anonymous reviewer for helpful feedback.

\section{Works Cited}

Adorno, Theodor W. 1976a. "On the Logic of the Social Sciences." In The Positivist Dispute in German Sociology, translated by Glyn Adey and David Frisby. New York: Harper \& Row.

—. 1976b. "Sociology and Empirical Research." In The Positivist Dispute in German Sociology, translated by Glyn Adey and David Frisby, 68-86. New York: Harper \& Row.

— 1991. “The Essay as Form.” In Notes to Literature: Volume One, edited by Rolf Tiedemann and Sherry Weber Nicholsen, 3-23. New York: Columbia University Press.

- 1993. "Theory of Pseudo-Culture." Telos, no. 95: 15-38. https://doi.org/10.3817/0393095015.

1995. Negative Dialectics. Translated by E.B. Ashton. New York: Continuum.

. 2005a. "Education After Auschwitz." In Critical Models: Interventions and Catchwords, translated by Henry W. Pickford, 191-204. New York: Columbia University Press.

—. 2005b. "Progress." In Critical Models: Interventions and Catchwords, translated by Henry W. Pickford. New York: Columbia University Press.

—. 2005c. "The Meaning of Working Through the Past." In Critical Models: Interventions and Catchwords, translated by Henry W. Pickford, 89-103. New York: Columbia University Press.

. 2006a. History and Freedom: Lectures 1964-1965. Edited by Rolf Tiedemann. Translated by Rodney Livingstone. Cambridge, UK: Polity Press. 
_. 2006b. "The Idea of Natural-History.” In Things Beyond Resemblance: Collected Essays on Theodor W. Adorno, translated by Robert Hullot-Kentor, 252-69. New York: Columbia University Press.

- 2019. Philosophical Elements of a Theory of Society. Edited by Tobias ten Brink and Marc Phillip Nogueira. Translated by Wieland Hoban. Cambridge: Polity.

Adorno, Theodor W., and Hellmut Becker. 1999. "Education for Maturity and Responsibility.” In History of the Human Sciences, translated by Robert French, Jem Thomas, and Dorothee Weymann, 12:21-34. 3.

Allen, Amy. 2016. The End of Progress: Decolonizing the Normative Foundations of Critical Theory. New York: Columbia University Press.

Benjamin, Walter. 2003. “On the Concept of History.” In Selected Writings, Volume 4: 1938-1940, edited by Howard Eiland and Michael W. Jennings, translated by Harry Zohn, 389-400. Cambridge, MA: Harvard University Press.

Bernstein, J.M. 2001. Adorno: Disenchantment and Ethics. Cambridge: Cambridge University Press.

Bonefeld, Werner. 2014. Critical Theory and the Critique of Political Economy: On Subversion and Negative Reason. New York: Bloomsbury Academic.

Celikates, Robin. 2018. "Critical Theory and the Unfinished Project of Mediating Theory and Practice." In The Routledge Companion to the Frankfurt School, edited by Peter Gordon, Espen Hammer, and Axel Honneth, 206-20. London: Routledge.

Cook, Deborah. 2020. “Adorno, Kant and Enlightenment." Kantian Review 25 (4): 541-57. https://doi.org/10.1017/S1369415420000400. 
Finlayson, James Gordon. 2007. "Political, Moral, and Critical Theory: On the Practical Philosophy of the Frankfurt School." In The Oxford Handbook of Continental Philosophy, edited by Michael Rosen and Brian Leiter. Oxford: Oxford University Press. https://doi.org/10.1093/oxfordhb/9780199234097.003.0019.

Freyenhagen, Fabian. 2017. “What Is Orthodox Critical Theory?” World Picture 12: 1-11.

Habermas, Jürgen. 1987. The Philosophical Discourse of Modernity: Twelve Lectures. Translated by Frederick G. Lawrence. Cambridge, MA: The MIT Press.

Honneth, Axel. 1979. "Communication and Reconciliation: Habermas' Critique of Adorno." Translated by Vincent Thomas and David Parent. Telos 39: 45-61. https://doi.org/10.3817/0379039045.

Horkheimer, Max. 1992a. "Materialism and Metaphysics." In Critical Theory: Selected Essays, translated by Matthew J. O'Connell, 10-46. New York: Continuum.

—. 1992b. "The Social Function of Philosophy." In Critical Theory: Selected Essays, translated by Matthew J. O'Connell, 252-72. New York: Continuum.

_. 1992c. "Traditional and Critical Theory." In Critical Theory: Selected Essays, translated by Matthew J. O'Connell, 188-243. New York: Continuum.

_. 1993. "Materialism and Morality." In Between Philosophy and Social Science: Selected Early Writings, translated by G. Frederick Hunter, Matthew S. Kramer, and John Torpey, 15-47. Cambridge, MA: The MIT Press.

Horkheimer, Max, and Theodor W. Adorno. 2002. Dialectic of Enlightenment: Philosophical Fragments. Edited by Gunzelin Schmid Noerr. Translated by Edmund Jephcott. Stanford: Stanford University Press. 
Hullot-Kentor, Robert. 2006. "Back to Adorno." In Things Beyond Resemblance: On Theodor W. Adorno, 23-44. New York: Columbia University Press.

Huseyinzadegan, Dilek. 2018. "Between Necessity and Contingency: A Critical Philosophy of History in the Dialectic of Enlightenment." Epoché 22 (2): 467-86. https://doi.org/10.5840/epoche2018111112.

Lotz, Christian. 2014. The Capitalist Schema: Time, Money, and the Culture of Abstraction. Lanham, MD: Lexington Books.

Nichols, Robert. 2018. "Progress, Empire, and Social Theory: Comments on The End of Progress: Decolonizing the Normative Foundations of Critical Theory." Political Theory 46 (5): 779-85. https://doi.org/10.1177/0090591718759469.

O'Kane, Chris. 2021. "Critical Theory and the Critique of Capitalism: An Immanent Critique of Nancy Fraser's 'Systematic' 'Crisis-Critique' of Capitalism as an 'Institutionalized Social Order."' Science \& Society 85 (2): 207-35. https://doi.org/10.1521/siso.2021.85.2.207.

Prusik, Charles. 2020. Adorno and Neoliberalism: The Critique of Exchange Society. New York: Bloomsbury Academic.

Thompson, Christiane. 2006. "Adorno and the Borders of Experience: The Significance of the Nonidentical for a 'Different' Theory of Bildung." Educational Theory 56 (1): 69-87. https://doi.org/10.1111/j.1741-5446.2006.00004.x.

Vázquez-Arroyo, Antonio Y. 2018. "Review - The End of Progress: Decolonizing the Normative Foundations of Critical Theory." Contemporary Political Theory 17: 224-27. https://doi.org/10.1057/s41296-017-0152-9.

Vogelmann, Frieder. 2021. "One Step Forward, Two Steps Back: Idealism in Critical Theory.” Constellations, 1-15. https://doi.org/10.1111/1467-8675.12548. 